\title{
Indikace $\mathbf{k}$ transplantaci srdce
}

\author{
Ivan Málek \\ Klinika kardiologie, Institut klinické a experimentální medicíny, \\ Praha, Česká republika
}

\begin{abstract}
Málek I (Klinika kardiologie, Institut klinické a experimentální medicíny, Praha, Česká republika). Indikace k transplantaci srdce. Cor Vasa 2008;50(3):129-132.

Transplantace srdce je řešením terminálních stadií srdečního selhání, kdy jsme vyčerpali ostatní možnosti léčby. Úspěšný výsledek můžeme očekávat pouze u správně indikovaného pacienta; toto rozhodnutí vyžaduje komplexní posouzení řady medicínských i sociálních faktorů. Algoritmus vyšetření zahrnuje posouzení: 1. pokročilosti stavu a jeho reverzibility, 2. předpokládané prognózy onemocnění při konzervativní léčbě, 3. přidružených onemocnění, která by mohla představovat kontraindikaci k transplantaci, 4. ostatních možností léčby srdečního selhání, které by mohly být alternativou nebo „mostem“ k transplantaci srdce, 5. compliance pacienta, 6. sociálních okolností. I když definitivní rozhodnutí je odpovědností specializovaného pracoviště, základní screening obvykle provádí praktický kardiolog-internista; na něm záleží, zda a kdy bude pacienta do př́slušného kardiocentra doporučovat.
\end{abstract}

Klíčová slova: Srdeční selhání - Transplantace srdce

Málek I (Department of Cardiology, Institute for Clinical and Experimental Medicine, Prague, Czech Republic). Indications for heart transplantation. Cor Vasa 2008;50(3):129-132.

Heart transplantation provides a solution to end-stage heart failure when all other therapeutic options have failed. A successful outcome can only be expected in a properly indicated patient; the decision requires a comprehensive consideration of a variety of medical and social factors. The algorithm of examination includes the assessment of: 1. current status and its reversibility; 2 . likely prognosis of the disease while receiving conservative therapy; 3 . associated conditions which might represent a contraindication to transplantation; 4. other therapeutic options in heart failure, which might serve as an alternative or a "bridge" to heart transplantation; 5. patient compliance; and 6. social aspects. Although the ultimate decision is the responsibility of a specialist center, initial screening is usually performed by the practicing cardiologist-internist; it is up to them whether and why they will refer the patient to the respective heart center.

Key words: Heart failure - Heart transplantation

Adresa: doc. MUDr. Ivan Málek, CSc., Klinika kardiologie, IKEM, Vídeňská 1958/9, 14021 Praha 4, Česká republika, e-mail: ivan.malek@medicon.cz

Transplantaci srdce (TxS) indikujeme u nemocných ve velmi pokročilé fázi srdečního selhání, které je refrakterní na medikamentózní léčbu a nelze jej řešit jiným způsobem. „Terminální“ fáze srdečního selhání je charakterizována výrazným omezením kvality života nemocného, velmi pokročilým stupněm dysfunkce levé komory (LK) a přítomností známek špatné prognózy. Z hlediska diagnózy indikujeme $\mathrm{k}$ transplantaci nejčastěji nemocné s dilatační kardiomyopatií (DKMP) a ischemickou chorobou srdeční (ICHS).

Kontraindikace srdeční transplantace jsou uvedeny v tabulce $I$.

\section{PROGNOSTICKÁ STRATIFIKACE}

Nejtěžší prognózu mají pacienti ve IV. třídě funkční klasifikace, jejichž stav vyžaduje pobyt na lůžku a parenterální podávání léků. U méně symptomatických pacientů (NYHA III) je pro stanovení indikace k TxS důležitý odhad další prognózy. $Z$ prognostického hlediska je TxS indikovaná tehdy, je-li dvouletá pravdě- podobnost přežití při konzervativní léčbě pod $50 \%$. Určení doby, kdy zařadit takového nemocného na čekací listinu je obtížným úkolem a vyžaduje zhodnocení řady faktorů, ${ }^{(1,2)}$ tabulka II.

\section{Význam spiroergometrie}

Spiroergometrie je zátěžový test, při kterém měříme spotřebu kyslíku $\left(\mathrm{VO}_{2}\right)$ a výdej kysličníku uhličitého $\left(\mathrm{VCO}_{2}\right)$ při jednotlivých stupních zátěže. Křivky výměny plynů probíhají paralelně až do okamžiku, kdy se začne uplatňovat anaerobní metabolismus, pak začne výdej $\mathrm{CO}_{2}$ převažovat nad $\mathrm{VO}_{2}$ a je dosaženo anaerobního prahu. V určité chvíli se křivka spotřeby kyslíku oploštuje a další zvyšování zátěže již nevede $\mathrm{k}$ vzestupu $\mathrm{VO}_{2}$, je dosaženo vrcholové (peak) hodnoty $\mathrm{VO}_{2}\left(\mathrm{pVO}_{2}\right)$. Hodnota $\mathrm{pVO}_{2}$ je pak oním ukazatelem, podle kterého posuzujeme další prognózu nemocného. Kromě spotřeby kyslíku stanovujeme též ventilační ekvivalent pro kysličník uhličitý $\left(\mathrm{VE} / \mathrm{VCO}_{2}\right)$, který vyjadřuje, kolik litrů vzduchu pacient proventi- 
Tabulka I

Kontraindikace ortotopické transplantace srdce

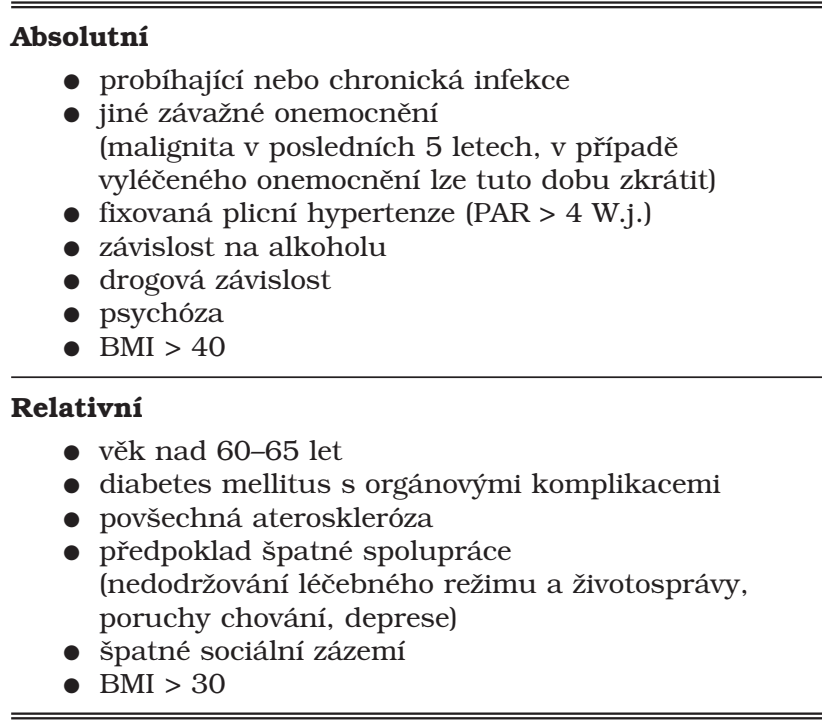

BMI - body mass index

luje k tomu, aby vydýchal 1 litr $\mathrm{CO}_{2}$. Abnormální ventilační odpověd’ na zátěž, charakterizovaná vysokým sklonem přímky, jež vyjadřuje vztah mezi ventilací a výdejem $\mathrm{CO}_{2}\left(\mathrm{VE} / \mathrm{VCO}_{2}\right.$ slope), je rovněž nepříznivou prognostickou známkou. ${ }^{(3)}$

Za výsledek testu, který předpovídá špatnou prognózu, se považuje hodnota $\mathrm{pVO}_{2}$ pod $10 \mathrm{ml} / \mathrm{kg} / \mathrm{min}$, pacienti nad $17 \mathrm{ml} / \mathrm{kg} / \mathrm{min}$ mají obvykle prognózu dobrou. $\mathrm{V}$ „šedé“ zóně mezi těmito hodnotami je důležitým ukazatelem hodnota stupně hyperventilace, která zvyšuje prognostickou závažnost výsledku.

\section{Význam pravostranné katetrizace}

Dlouhodobé zvýšení tlaku v malém oběhu vede postupně ke změnám $\mathrm{v}$ plicních arteriolách, stoupá plicní rezistence a původně postkapilární hypertenze se stává smíšenou s významným podílem prekapilární složky. Zvyšuje se transpulmonální gradient (TPG) a plicní arteriolární rezistence (PAR).

Nález prekapilární plicní hypertenze se ukázal jako významný limitující faktor pro TxS. ${ }^{(4)}$ Po ortotopické transplantaci srdce je pravá komora štěpu vystavena náhle vysokému odporu při hypertenzi v malém oběhu přijemce, následkem je její selhávání, v krajním případě až úplné mechanické selhání vedoucí ke ztrátě funkce štěpu. Posouzení nálezu, stupně a reverzibility plicní hypertenze je proto nezbytnou součástí vyšetřovacího programu kandidáta srdeční transplantace. U nemocného na čekací listině je nutno pravostrannou katetrizaci provádět opakovaně. $Z$ naměřených hodnot tlaku v plicnici, tlaku v zaklínění a minutového srdečního výdeje, se počítají hodnoty TPG a PAR, které jsou pro posouzení možnosti TxS a jejího rizika zásadní. Při nálezu vysokého TPG a PAR ( $\geq 15 \mathrm{~mm} \mathrm{Hg}$, resp. $\geq 3 \mathrm{~W}$.j.) je nezbytný postup testování reverzibility plicní hypertenze látkami, které mají převažující nebo selektivní účinek na cévy malého oběhu (např. prostaglandin E1). Teprve opakovaný nález těžké fixované plicní prekapilární hypertenze (TPG > $20 \mathrm{~mm} \mathrm{Hg} \mathrm{a/nebo} \mathrm{PAR} \mathrm{>} 4$ W.j.) při maximální terapii nás opravňuje stanovit kontraindikaci k OTS. Tyto případy jsou vzácné.

Nemocné s menším stupněm plicní hypertenze je možné $\mathrm{k}$ TxS indikovat, ale za předpokladu použití srdce od dárce vyšší hmotnosti a peroperačního podávání kysličníku dusnatého. Při pečlivém předoperačním testování a peroperačním ovlivnění plicní hypertenze jsou výsledky TxS u pacientů s plicní hypertenzí srovnatelné s ostatními operovanými. ${ }^{(5)}$ Po srdeční transplantaci dochází obvykle k ústupu plicní hypertenze. Tam, kde zvýšená plicní rezistence přetrvává, může být další vývoj nepř́íznivý. ${ }^{(6)}$

\section{PR̆IDRUŽENÁ ONEMOCNĚNÍ}

Při rozhodování o vhodnosti TxS mohou být problémem přidružená onemocnění, která nejsou absolutní kontraindikací, ale (zvláště při jejich kumulaci) mohou být indikačním problémem.

Tabulka II

Některé faktory, které nepříznivě ovlivňují prognózu chronického srdečního selhání

\section{Klinické}

nízká tolerance zátěže (NYHA III-IV, $\left.\mathrm{pVO}_{2}<10 \mathrm{ml} / \mathrm{kg} / \mathrm{min}\right)$

intolerance léčby ACE-I a betablokátory

klidová tachykardie a hypotenze

přitomnost III. ozvy

váhový úbytek

opakované dekompenzace srdečního selhání

\section{Hemodynamické}

nízká EF LK (PK)

nález výrazné dilatace LK a mitrální regurgitace zvýšený centrální žilní tlak a tlak v plicnici nízký srdeční výdej a vysoká systémová rezistence

\section{Biochemické}

zvýšená koncentrace noradrenalinu v séru zvýšená koncentrace natriuretického peptidu zvýšená koncentrace endotelinu

zvýšená koncentrace kyseliny močové snížená koncentrace sérového natria, kalia a magnezia zvýšení sérového bilirubinu a kreatininu

\section{Elektrofyziologické}

přitomnost komorových extrasystol

výskyt komorových tachykardií

fibrilace síní

výskyt převodní poruchy

(blokády levého raménka Tawarova)

EF LK - ejekční frakce levé komory, PK - pravá komora, LK - levá komora

Řada nemocných má známky poruchy plicních funkcí; mohou souviset se srdečním onemocněním nebo může jít o preexistující plicní onemocnění nejčastěji chronickou obstrukční bronchopulmonální nemoc (CHOPN). Při nálezu vitální kapacity pod 50 \% a $\mathrm{FEV}_{1}$ pod $40 \%$ náležité hodnoty již anesteziolog TxS obvykle nedoporučí.

Častým problémem je porucha funkce ledvin. Je třeba vyloučit preexistující onemocnění ledvin, kdy častou příčinou poruchy je hypertenze, tepenná ateroskleróza a diabetes. Tyto choroby se často sdru- 
žují, zvláště u kandidátů transplantace vyššího věku. Situaci komplikuje skutečnost, že u nemocných s pokročilým srdečním selháním jsou známky porušené funkce ledvin přitomny i bez preexistující renální choroby. Porucha je častá zvláště v období dekompenzace a míra úpravy po léčbě je důležitým vodítkem při indikační rozvaze. $\mathrm{V}$ terminálním stadiu srdečního selhání se může stát závažná renální porucha kontraindikací srdeční transplantace, v takovém případě lze uvažovat o kombinované transplantaci srdce a ledviny. ${ }^{(7)}$

U starších pacientů je častým problémem ateroskleróza periferních cév, která představuje relativní kontraindikaci TxS. Rozhodování je zde individuální, vždy je však nutné počítat $s$ tím, že při imunosupresivní potransplantační léčbě bude ateroskleróza progredovat. ${ }^{(8)}$ Podobně obezita zvyšuje úmrtnost při operaci a riziko infekčních komplikací.(9) Obezita se tak může stát relativní či absolutní kontraindikací TxS.

Údaj o výskytu maligního tumoru umožňuje bezpečnou indikaci pouze tehdy, byl-li tumor zcela vyléčen a v posledních pěti letech nebyly žádné známky recidivy. Výjimkou jsou maligní tumory srdce a některé kožní nádory (bazaliom a spinocelulární karcinom). ${ }^{(10)}$ $\mathrm{V}$ praxi někdy interval pěti let striktně nedodržíme. Indikovali jsme např. mladého pacienta v terminálním stadiu srdečního selhání po recentně provedené nefrektomii pro Grawitzův tumor. Posuzování je individuální, vždy vyžadujeme vyjádření onkologa.

Důležitým momentem při rozhodování o TxS jsou i psychosociální faktory. Transplantaci nebudeme indikovat $\mathrm{u}$ pacienta $\mathrm{s}$ oligofrenií a těžkou demencí; z psychiatrických onemocnění je kontraindikací schizofrenie a těžká deprese se suicidiálními pokusy. V některých případech je rozhodování obtížné, nebot srdeční selhání se samo o sobě podílí na zhoršení psychiky nemocného. Vyžadujeme vyjádření psychiatra, jehož úloha je $\mathrm{v}$ této situaci někdy obtížná. Transplantace je kontraindikována též u alkoholiků a nemocných drogově závislých. Pacient, u něhož uvažujeme o TxS, má mít též dobré sociální zázemí a tato informace i kontakt $\mathrm{s}$ rodinou patří $\mathrm{k}$ nezbytným postupům.

\section{REVERZIBILNÍ FAKTORY SRDEČNÍHO SELHÁNÍ}

Při úvaze o TxS je důležité si uvědomit, že i stavy, které se jeví jako terminální srdeční selhání, mohou být někdy potenciálně reverzibilní a po odstranění jejich prríčiny může být další průběh příznivý.

$Z$ onemocnění, které se manifestují jako DKMP lze vyčlenit několik potenciálně reverzibilních stavů (tabulka III).

Důležitým údajem je doba trvání symptomů. U nemocných s krátkou anamnézou dochází po zavedení léčby ve většině případů ke kompenzaci a zlep-

Tabulka III

Potenciálně reverzibilní kardiomyopatie

- lymfocytární myokarditida

- hypertenzní kardiomyopatie

- alkoholická kardiomyopatie

- těhotenská kardiomyopatie

- „arytmická“ kardiomyopatie šení srdeční funkce. U pacientů přijatých v těžkém stavu může být užitečné sledování dynamiky BNP (brain natriuretic peptid). Časný pokles koncentrace BNP v krvi predikuje následný příznivý průběh onemocnění. ${ }^{12)}$

Dalším možným reverzibilním faktorem je ischemie myokardu. U nemocných $\mathrm{s}$ ischemickou dysfunkcí levé komory má být vždy provedena selektivní koronarografie a při nálezu na věnčitých tepnách, umožňujícím chirurgickou rekonstrukci, má být zváŽena revaskularizační operace. ${ }^{(13)}$

Častou př́ičinou nepříznivého průběhu srdečního selhání je nedostatečné využívání současných možností léčby, především farmakoterapie a resynchronizační léčby. ${ }^{(14)}$ Př́ičinou může být i špatná adherence nemocného k léčbě; tito nemocní nejsou vhodnými kandidáty srdeční transplantace. Rozvaha, zda u pacienta odesílaného jako „kandidát TxS“ jsou využity všechny léčebné možnosti, je proto nedílnou součástí předtransplantačního vyšetření.

\section{VYŠETR̆ENÍ PR̆İJEMCE A PÉC̆E O NEMOCNÉ NA ČEKACÍ LISTINĔ}

První vyšetření (pokud pacient není v těžkém stavu) je obvykle provedeno v ambulanci, kde lze získat informace o funkci levé komory a toleranci zátěže. Zde také posuzujeme, zda-li lze uvažovat o jiných způsobech léčby a zda nejsou přítomny kontraindikace pro případnou srdeční transplantaci.

Pokud je stav posouzen jako pokročilé srdeční selhání, je nemocný pozván $\mathrm{k}$ podrobnému vyšetření při hospitalizaci. Vyloučíme-li možnost jiného způsobu léčby, a neshledáme-li důvody proti transplantaci, podáme nemocnému podrobnou informaci o možném přínosu, riziku a omezeních, které může po zařazení do programu očekávat. $\mathrm{V}$ případě kladného postoje nemocného jsou pak provedena vyšetření obvyklá před kardiochirurgickým výkonem včetně sanace infekčních fokusů.

Specifickým předtransplantačním testem je pravostranná katetrizace, při které posuzujeme stupeň plicní hypertenze a její prekapilární složky. Při zvýšení plicní rezistence provádíme testování prostaglandinem E1, popřípadě kysličníkem dusnatým. Dalším nezbytným vyšetřením je stanovení protilátek proti panelu lymfocytů a vyšetření protilátek proti antilymfocytálním globulinům, které budou podávány peroperačně.

Po schválení indikace na společném indikačním pohovoru je nemocný zařazen na čekací listinu, zde jsou nemocní řazeni podle krevních skupin a váhových kategorií $\mathrm{v}$ pořadí, $\mathrm{v}$ jakém byli indikováni. Je vyčleněna kategorie urgentních př́ijemců, kteří mají vždy při nabídce dárce přednost. Nemocné na čekací listině sledujeme ve spolupráci se spádovým kardiologem obvykle ve 2-3měsíčních intervalech. Kontrolu je možné provést ve specializované ambulanci srdečního selhání, kontroly spojené s pravostrannou katetrizací je vhodné provést při krátké hospitalizaci. Pravostranná katetrizace nám umožňuje především sledovat vývoj plicní hypertenze, přispívá však i k optimalizaci léčby srdečního selhání. V některých případech se klinický stav zlepší natolik, že můžeme uvažovat o vyřazení $\mathrm{z}$ čekací listiny; tento postup 
vyžaduje objektivní doklad zlepšení tolerance zátěže a poklesu koncentrace natriuretických peptidů. Vyřazení $z$ čekací listiny je často pouze dočasné. Způsob péče o nemocné na čekací listině představuje model, který je žádoucí aplikovat u nemocných s pokročilým srdečním selháním v širším měřítku.

Spolupráce pražského a brněnského transplantačního centra se uskutečňuje následovně: každé $z$ center má vlastní čekací listinu a vlastní odběrovou oblast (Čechy, resp. Morava). Při výskytu vhodného dárce má vždy přednost př́jemce $\mathrm{v}$ urgentním pořadí, nezávisle na odběrové oblasti. To umožňuje optimální využití dárců pro př́ijemce, kteří jsou v těžkém stavu. Je realitou současné doby, že naprostá většina TxS se provádí právě u těchto urgentních prríjemců.

\section{LITERATURA}

1. Aaronson KD, Schwartz JS, Chen (tm), et al. Development and prospective validation of a clinical index to predict survival in ambulatory patients referred for cardiac transplant evaluation. Circulation 1997;95:2660-7.

2. Smits JM, Deng MC, Hummel M, et al. A prognostic model for predicting waiting-list mortality for a total national cohort of adult heart-transplant candidates. Transplantation 2003;76:1185-9.

3. Lupínek P. Úloha spiroergometrie při odhadu prognózy nemocných s chronickým srdečním selháním. Cor Vasa 2002;44:477-80.

4. Kakáč J, Málek I, Hrnčárek M, a spol. Testování plicní hypertenze u kandidátů ortotopické transplantace srdce pomocí prostaglandinu E1. Cor Vasa 1996;38:251-7.

5. Al-Hiti H, Kettner J, Málek I. Transplantace srdce u nemocných s těžkou plicní hypertenzí. Cor Vasa 2000; 42:1 [Abstrkt].

6. Goland S, Czer LSC, Kass RM, et al. Pre-existing pulmonary hypertension in patients with end-stage heart failure: impact on clinical outcome and hemodynamic follow-up after orthotopic heart transplantation. J Heart Lung Transplantation 2007;26:312-8.

7. Blanche C, Valenza M, Czer LS, et al. Combined heart and kidney transplantation with allografts from the same donor. Ann Thorac Surg 1994;58:1135-8.

8. Erdoes LS, Hunter GC, Venerus BJ, et al. Prospective evaluation of peripheral vascular disease in heart transplant recipients. J Vasc Surg 1995;22:434-40.

9. Lietz K, John R, Burke EA, et al. Pretransplant cachexia and morbid obesity are predictors of increased mortality after heart transplantation. Transplantation 2001;72: 277-83.

10. Hošková L, Málek I, Podzimková M, et al. Nádorová onemocnění po transplantaci srdce. Cor Vasa 2002;44:77-80.

11. Maricle RA, Hosenpud JD, Norman DJ, et al. The lack of predictive value of preoperative psychologic distress for postoperative medical outcome in heart transplant recipients. J Heart Lung Transplant 1991;10:942-7.

12. Rothenburger M, Wichter T, Schmid C, et al. Aminoterminal pro type $\mathrm{B}$ natriuretic peptide as a predictive and prognostic marker in patients with chronic heart failure. J Heart Lung Transplant 2004;23:1189-97.

13. Florian M, Málek I, Pirk J, Frídl P. Výsledky chirurgické revaskularizace myokardu u pacientů s významnou předoperační systolickou dysfunkcí levé komory. Cor Vasa 2001;43:85-8.

14. Cleland JGF, Cohen-Solal A, Aguilar J, et al. for the IMPROVEMENT of Heart Failure Programme Committees and Investigators and the Study Group on Diagnosis of the Working Group on Heart Failure of the European Society of Cardiology. Management of heart failure in primary care (the IMPROVEMENT of Heart Failure Programme): an International Survey. Lancet 2002;360: 1631-9.

Došlo do redakce 2. 1. 2008

Přijato k otištění 29. 1. 2008 